\title{
Diagnostic and Prognostic Value of Neopterin Levels in Serum and Bronchoalveolar Lavage Fluid in Sepsis
}

\section{Bronkoalveolar Lavaj Sıvısında ve Serumda Ölçülen Neopterinin Sepsiste Tanısal ve Prognostik Değerinin Saptanması}

\author{
Ömer Karaşahin ${ }^{1 *}$, Kenan Hızel ${ }^{2}$, Cemalettin Aybay ${ }^{3}$, Müge Aydoğdu ${ }^{4}$, E. Füsun Karaşahin ${ }^{5}$ \\ 1SBÜ Erzurum Bölge Ë̆itim ve Araştırma Hastanesi Enfeksiyon Hastallklar ve Klinik Mikrobiyoloji Eræurum \\ ${ }^{2}$ Gazi Üniversitesi Enfeksiyon Hastaliklar ve Klinik Mikrobiyoloji Anabilim Daln Ankara \\ ${ }^{3}$ Gazi Üniversitesi Immünoloji Anabilim Dali Ankara \\ ${ }^{4}$ Gazi Universitesi Gögüs Hastahklar Anabilim Dalı Ankara \\ ${ }^{5}$ Eræurum İl Sağhlk Müdürlïgü Halk Sağh̆ğ Hizmetleri Başkanliğ Erzurum
}

\begin{abstract}
Objective: This study aimed to measure neopterin levels in serum and bronchoalveolar lavage fluid to determine the diagnostic and prognostic value of neopterin in sepsis.

Materials and Methods: This descriptive, cross-sectional study included intensive care patients over the age of 18 who underwent invasive mechanical ventilation and blood and bronchoalveolar lavage sampling at admission. Forty-five patients were analyzed retrospectively as those with sepsis $(n=22)$ and without sepsis $(n=23)$.
\end{abstract}

Results: Serum and bronchoalveolar lavage neopterin concentrations were statistically significantly higher in patients with sepsis. Neopterin level in serum and bronchoalveolar lavage fluid had good predictive value for the diagnosis of sepsis, with cut-off values of $22.04 \mathrm{nmol} / \mathrm{L}$ (Area under curveAUC $85.8 \%$ ) and $2.61 \mathrm{nmol} / \mathrm{L}$ (AUC $76.1 \%$ ), respectively. Creactive protein, on the other hand, had a predictive value of $86.1 \%$ for the diagnosis of sepsis, with a cut-off value of 73.25 $\mathrm{mg} / \mathrm{L}$. Serum neopterin and C-reactive protein were determined as independent risk factors for sepsis. When these two biomarkers were used together, they showed the best predictive value (AUC 93.3\%) for the diagnosis of sepsis. Bronchoalveolar lavage neopterin correlated with clinical pulmonary infection score. Serum neopterin level was significantly higher in sepsis patients who developed septic shock than in those who did not.

Conclusion: Serum neopterin had comparable diagnostic value in sepsis to the widely used biomarker, procalcitonin. Combined use with $\mathrm{C}$-reactive protein increases the diagnostic value, specificity, and sensitivity of serum neopterin in sepsis. Serum neopterin can also be used as a prognostic indicator and may be predictive of the rapidly developing processes that lead to shock. Despite the lower value of bronchoalveolar lavage neopterin for the diagnosis of sepsis, its correlation with clinical pulmonary infection score suggests that it may indicate disease severity in ventilator-associated pneumonia.

Key Words: Neopterin, bronchoalveolar lavage, sepsis, biomarker

\begin{abstract}
Özet
Amaç: Çalışmamızda, sepsis patogenezinde doğrudan yer alan monosit-makrofajların aktivasyonunu yansitan neopterin, serum ve bronkoalveolar lavaj sıvında ölçülerek sepsisteki tanı ve prognostik değerini tespit etmek amaçlanmıştır.

Gereç ve Yöntem: Bu tanımlayıcı-kesitsel çalıșma yoğun bakım ünitesinde yatışları sırasında invaziv mekanik ventilasyon uygulanan, serum ve bronkoalveolar lavaj sivis1 alınan 18 yaşından büyük hastalarda gerçekleştirilmiştir. Çalışmaya dahil edilen 45 hastanın verileri, sepsis olanlar $(\mathrm{n}=22)$ ve olmayanlar $(n=23)$ olarak iki gruba ayrlarak geriye yönelik olarak incelenmiştir.

Bulgular: Serum ve bronkoalveolar lavaj sivisinda neopterin değeri, sepsis olan hastalarda istatistiksel anlamlı olarak daha yüksektir. Serum ve bronkoalveolar lavaj sivisında neopterin düzeyi, sırasıyla 22,04 nmol/L (Eğri altı alan-EAA \%85,8) ve $2,61 \mathrm{nmol} / \mathrm{L}$ (EAA \%76,1) kesme değerleriyle sepsis tanıs1 için iyi öngörücü değere sahipti. C reaktif protein ise $73,25 \mathrm{mg} / \mathrm{L}$ kesme değeriyle sepsis tanısı için \%86,1 öngörü değerine sahipti. Serum neopterin ve $\mathrm{C}$ reaktif protein sepsis için bağımsız risk faktörü olarak saptandı. Bu iki biyobelirteç birlikte kullanıldığında sepsis tanısı için en ivi öngörücü değeri (EAA $\% 93,3$ ) gösterdi. Klinik pulmoner enfeksiyon skoru ile de bronkoalveolar lavaj neopterin arasında korelasyon vardir. Sepsis olan hastalarda, septik şok gelișenlerde, gelișmeyenlere göre serum neopterin açısından istatistiksel anlamlı fark saptanmıştır.
\end{abstract}

Sonuç: Sepsis tanısında serum neopterin kullanımının tanı değeri, yaygın olarak kullanılan prokalsitonin kadar etkilidir. Creaktif protein ile birlikte kullanımı, sepsis tanı değerini, özgüllüğ̈üü ve duyarlılı̆ıııı artırır. Buna ek olarak, prognostik bir gösterge olarak kullanılabilir ve şoka neden olan, hızla gelișen sürecleri öngören bir parametre olabilir. Bronkoalveolar lavaj neopterinin sepsis tanısındaki daha düşük tanı gücüne rağmen, klinik pulmoner enfeksiyon skoru ile korelasyonu, ventilatör ilișkili pnömoni hastalık şiddetini gösterebileceğini düşündürmektedir.

Anahtar Kelimeler: Neopterin, bronkoalveolar lavaj, sepsis, biyobelirteç 
Karaşahin ve ark. / The value of neopterin in the diagnosis of sepsis

\section{Objective}

Sepsis is a complicated disease process that arises from the body's response to infection and leads to potentially fatal organ dysfunction (1). This widespread public health problem is seen in 1 of every 17 hospitalizations and 1 in 3 hospital deaths (2). Sepsis is a clinical continuum, and the mortality rate increases as it progresses to septic shock. With a rising incidence and high mortality, it is among the most common causes of death in intensive care units (ICU) other than coronary ICUs (3). The signs and symptoms of sepsis syndrome can be confused with noninfectious systemic inflammatory diseases. The gold standard diagnostic method is the isolation of microorganisms from blood culture together with the clinical picture of infection (1). However, even with blood culture, microorganisms can only be detected after 48 to 72 hours and at a frequency of only $30 \%$ (4). There is no gold standard biochemical marker for use in the diagnosis and prognosis of sepsis. Early goal-directed therapy within the first hour has been reported to reduce mortality (1). Therefore, highly sensitive and specific biomarkers that can provide early and reliable results in the diagnosis of sepsis are needed (1, 3-6). In this context, C-reactive protein (CRP) and procalcitonin (PCT) are indicators that can be measured anywhere on admission to intensive care, providing prognostic information for sepsis and simply assessing the inflammatory response $(7,8)$. The current guidelines of the Surviving Sepsis Campaign also state that procalcitonin can be used to contribute to the management of infection therapy (1). Neopterin (NT) is a low-molecular-weight pyridine produced through guanosine triphosphate metabolism when monocytes and macrophages are stimulated by interferon gamma (IFN- $\gamma$ ) synthesized by $\mathrm{T}$ lymphocytes and natural killer cells (9). NT is a biomarker of the cellular immune response mediated by lymphocytes and macrophages. Because NT is a monocyte/macrophage-specific mediator produced upon stimulation by microbial products (lipopolysaccharide, endotoxin) from the organisms involved in the pathogenesis of sepsis as well as by cytokines released upon activation of the mononuclear phagocytic system (tumor necrosis factor alpha [TNF- $\alpha$ ], interleukin-1 [IL$1]$, and IFN- $\gamma$ ), it provides information about the systemic inflammatory response and the development of septic complications (10). NT was also shown to be produced by activated endothelial cells and biosynthesized together with vasoactive compounds (e.g., prostacyclin PGI2, nitric oxide) in response to endotoxins, $\mathrm{TNF}-\alpha$, and IFN- $\gamma$ (11). The aim of this study was to determine the diagnostic and prognostic value of serum and bronchoalveolar lavage (BAL) fluid NT levels in sepsis. The secondary objective was to determine the value of using NT together with other routinely used biomarkers in the diagnosis of sepsis.

\section{Materials and Methods}

This descriptive, cross-sectional study included patients 18 years or older who underwent invasive mechanical ventilation and had BAL samples collected via bronchoscopy during ICU follow-up for respiratory failure. Samples collected over a 9month period were studied in March 2015.The study received ethics committee approval and written informed consent was obtained from all participants or their legal representatives (University Clinical Research Ethics Committee date: 25 February 2015 no:105). This article was adapted from a dissertation entitled "Determination of the Diagnostic and Prognostic Value of Neopterin Measured in Bronchoalveolar Lavage Fluid and Serum in Intensive Care Patients." The 45 patients included in the study were grouped as those with and without sepsis, and the sepsis patients were further subgrouped as those who progressed to septic shock and those who did not. The results of urine, wound site, BAL, intracatheter, and peripheral blood cultures collected at the clinician's discretion upon ICU admission to determine the infectious focus were recorded from the laboratory archives. As biomarkers, NT, PCT, CRP, albumin, creatinine, international normalized ratio (INR), alanine aminotransferase (ALT), white blood cell (WBC), and platelet (PLT) levels were obtained from the patients' files to be used as values in the diagnosis of sepsis. After performing direct microscopic examination and microbiological culture, blood and BAL samples were stored at $-80^{\circ} \mathrm{C}$ for later NT analysis. Blood samples obtained simultaneously with BAL fluid were collected into a tube with no anticoagulants and within 30 minutes were centrifuged at $3000 \mathrm{rpm}$ for 10 minutes. The separated serum and BAL samples were stored at $-80^{\circ} \mathrm{C}$ until analysis. Each sample was thawed on the day of analysis. Quantitative analysis of NT in human serum, plasma, urine, and cell culture supernatant was performed using a high-affinity NT-specific monoclonal antibodybased competitive ELISA (enzyme-linked immunosorbent assay) kit (Immunoguide, Ankara, Turkey). The lowest detectable NT concentration of the kit used was $1 \mathrm{nmol} / \mathrm{L}$, intraassay variability (intraassay $\mathrm{CV}$ ) was $<8.2-54 \% \mathrm{nmol} / \mathrm{L}$, and 
interassay variability (interassay $\mathrm{CV}$ ) was $<8.2-$ $55 \% \mathrm{nmol} / \mathrm{L}$.

Definitions: Sepsis is a life-threatening organ dysfunction caused by an abnormal host response to infection. Sepsis was defined as microbiologically documented or clinical diagnosis of infection with at least 2 of the following criteria: (a) body temperature over $38^{\circ} \mathrm{C}$ or under $36^{\circ} \mathrm{C}$, (b) heart rate above $90 / \mathrm{min}$, (c) respiratory rate above $20 / \mathrm{min}$ or arterial $\mathrm{CO}_{2}$ pressure below $32 \mathrm{mmHg}$, and (d) leukocyte count higher than $12000 / \mathrm{mm}^{3}$ or lower than $4000 / \mathrm{mm}^{3}$

Table 1: Distribution of the patients' demographic characteristics, underlying diseases, risk factors, clinical scores, and initial biomarker levels according to the presence of sepsis

\begin{tabular}{|c|c|c|c|}
\hline & Sepsis $(n=22)$ & Non-sepsis $(n=23)$ & $\mathrm{p}^{*}$ \\
\hline Age (years) ${ }^{* *}$ & $75(32-88)$ & $73(36-96)$ & 0.439 \\
\hline \multirow{2}{*}{$\begin{array}{ll}\text { Sex } & \text { Male } \\
& \text { Female }\end{array}$} & $16(53.3 \%)$ & $14(46.7 \%)$ & 0.399 \\
\hline & $6(40.0 \%)$ & $9(60.0 \%)$ & \\
\hline APACHE-II** & $23(18-38)$ & $21(8-32)$ & 0.007 \\
\hline $\mathrm{CCI}^{* *}$ & $7(3-10)$ & $6(4-8)$ & 0.224 \\
\hline ICU LOS (days)** & $28.50(6-57)$ & $13(3-104)$ & 0.001 \\
\hline IMV duration (days)** & $21(6-51)$ & $8(3-104)$ & 0.001 \\
\hline Pre-ICU hospital LOS (days)** & $7(2-37)$ & $3(1-38)$ & 0.201 \\
\hline \multicolumn{4}{|l|}{ Underlying diseases } \\
\hline $\begin{array}{l}\text { Chronic obstructive pulmonary } \\
\text { disease }\end{array}$ & $8(34.8 \%)$ & $15(65.2 \%)$ & 0.053 \\
\hline Solid organ tumor & $10(58.8 \%)$ & $7(41.2 \%)$ & 0.624 \\
\hline Diabetes mellitus & $7(43.8 \%)$ & $9(56.2 \%)$ & 0.758 \\
\hline Coronary artery disease & $4(44.4 \%)$ & $5(55.6 \%)$ & 0.530 \\
\hline Chronic kidney disease & $5(83.3 \%)$ & $1(16.7 \%)$ & 0.084 \\
\hline Connective tissue disease & $3(100 \%)$ & - & 0.109 \\
\hline Asthma & - & $2(100 \%)$ & 0.256 \\
\hline Bronchiectasis & $1(100 \%)$ & - & 0.489 \\
\hline \multicolumn{4}{|l|}{ Biomarkers** } \\
\hline BAL NT (nmol/L) & $5.10(0.24-101.73)$ & $0.93(0.11-12.75)$ & 0.003 \\
\hline Serum NT (nmol/L) & $39.52(2.94-385.07)$ & $5.90(0.12-60.09)$ & 0.001 \\
\hline CRP (mg/L) & $153(15-402)$ & $55(2-158)$ & 0.001 \\
\hline PCT (ng/ml) & $1.75(0.24-75.0)$ & $0.25(0.10-2.46)$ & 0.001 \\
\hline Albumin (mg/dL) & $2.40(1.60-3.20)$ & $2.9(2.00-4.00)$ & 0.003 \\
\hline PLT $\left(10^{9} / \mathrm{L}\right)$ & $163(22.8-544)$ & $245(71.4-605)$ & 0.044 \\
\hline WBC $\left(10^{9} / \mathrm{L}\right)$ & $12.6(1.0-38.8)$ & $13.5(1.3-39.0)$ & 0.964 \\
\hline INR & $1.30(0.88-2.00)$ & $1.00(0.90-1.60)$ & 0.014 \\
\hline Creatinine (g/dL) & $1.4(0.5-7.0)$ & $0.7(0.1-2.5)$ & 0,002 \\
\hline $\operatorname{ALT}(\mathrm{U} / \mathrm{L})$ & $24(33-1032)$ & $24(6-76)$ & 0.601 \\
\hline \multicolumn{4}{|l|}{ Sepsis complications } \\
\hline Septic shock & $12(54.5 \%)$ & - & \\
\hline ARDS & $12(54.5 \%)$ & $8(34.8 \%)$ & 0.151 \\
\hline Mortality & $18(81.8 \%)$ & $9(39.1 \%)$ & 0.004 \\
\hline
\end{tabular}

*Mann-Whitney U or chi-square test. **Median (minimum - maximum)

APACHE II: Acute Physiology and Chronic Health Evaluation II, ICU: Intensive care unit, LOS: Length of stay, IMV: Invasive mechanical ventilation, CCI: Charlston comorbidity index, BAL: Bronchoalveolar lavage, ARDS: Acute respiratory distress syndrome, NT: Neopterin, CRP: C-Reactive protein, PCT: Procalcitonin, PLT: Platelets, WBC: White blood cells, INR: International normalized ratio, ALT: Alanine aminotransferase 


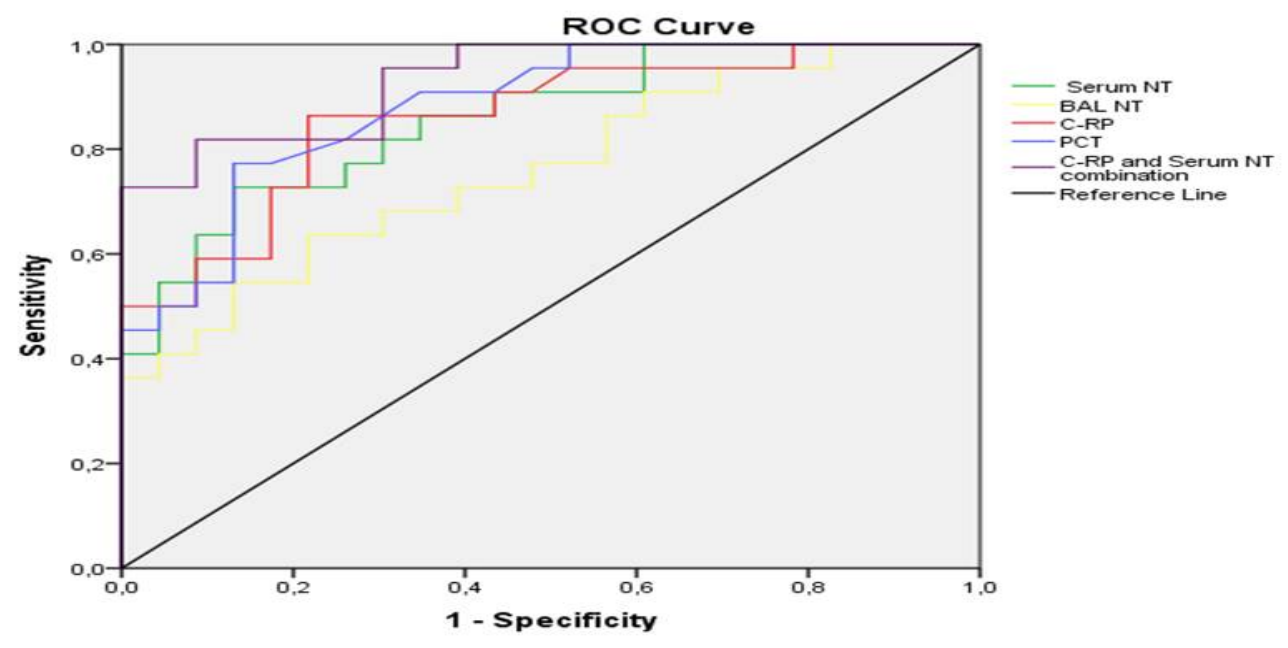

Figure 1. ROC curves of serum NT, BAL NT, CRP, PCT, and the combination of serum NT and CRP for the diagnosis of sepsis

Table 2: The diagnostic value, sensitivity, specificity, PPV, and NPV of biomarkers on day 2 according to the cut-off values determined for the diagnosis of sepsis.

\begin{tabular}{|c|c|c|c|c|c|c|c|}
\hline Variable & $\begin{array}{c}\text { AUC } \\
(95 \% \text { CI })\end{array}$ & $\begin{array}{l}\text { Cut- } \\
\text { off }\end{array}$ & $\begin{array}{c}\text { Sensitivity } \\
(\%)\end{array}$ & $\begin{array}{c}\text { Specificity } \\
(\%)\end{array}$ & PPV (\%) & NPV (\%) & $\mathrm{p}^{*}$ \\
\hline $\begin{array}{l}\text { BAL NT } \\
(\mathrm{nmol} / \mathrm{L})\end{array}$ & $\begin{array}{c}76.1 \\
(62.2-90.0)\end{array}$ & 2.61 & 63.6 & 78.3 & 74.5 & 68.2 & 0.001 \\
\hline $\begin{array}{l}\text { Serum NT } \\
(\mathrm{nmol} / \mathrm{L})\end{array}$ & $\begin{array}{c}85.8 \\
(75.1-96.4)\end{array}$ & 22.04 & 72.7 & 87.0 & 84.8 & 76.1 & 0.001 \\
\hline CRP (mg/L) & $\begin{array}{c}86.1 \\
(75.3-96.8)\end{array}$ & 73.25 & 86.4 & 78.3 & 79.9 & 85.2 & 0.001 \\
\hline РСТ (ng/ml) & $\begin{array}{c}88.2 \\
(78.7-97.7)\end{array}$ & 0.68 & 77.3 & 88.7 & 87.2 & 79.6 & 0.001 \\
\hline $\begin{array}{l}\text { Albumin } \\
(\mathrm{mg} / \mathrm{dL})\end{array}$ & $\begin{array}{c}75.6 \\
(61.5-89.7)\end{array}$ & 3.05 & 47.8 & 95.5 & 91.4 & 64.6 & 0.003 \\
\hline $\operatorname{PLT}\left(10^{6} / \mathrm{mm}^{3}\right)$ & $\begin{array}{c}67.5 \\
(51.7-83.3)\end{array}$ & 142 & 54.5 & 91.3 & 86.2 & 66.7 & 0.044 \\
\hline INR & $\begin{array}{c}71.1 \\
(55.5-86.8)\end{array}$ & 1.29 & 54.5 & 91.3 & 86.2 & 66.7 & 0.015 \\
\hline $\begin{array}{l}\text { Creatinine } \\
(\mathrm{g} / \mathrm{dL})\end{array}$ & $\begin{array}{c}76.5 \\
(62.4-90.6)\end{array}$ & 1.08 & 81.8 & 69.4 & 72.8 & 79.2 & 0.002 \\
\hline
\end{tabular}

$* \overline{\mathrm{ROC}}$ analysis; Youden index was used to determine cut-off point.

AUC: Area under the curve, CI: Confidence interval, PPV: Positive predictive value, NPV: Negative predictive value, NT: Neopterin, CRP: C-reactive protein, PCT: Procalcitonin, PLT: Platelets, INR: International normalized ratio 


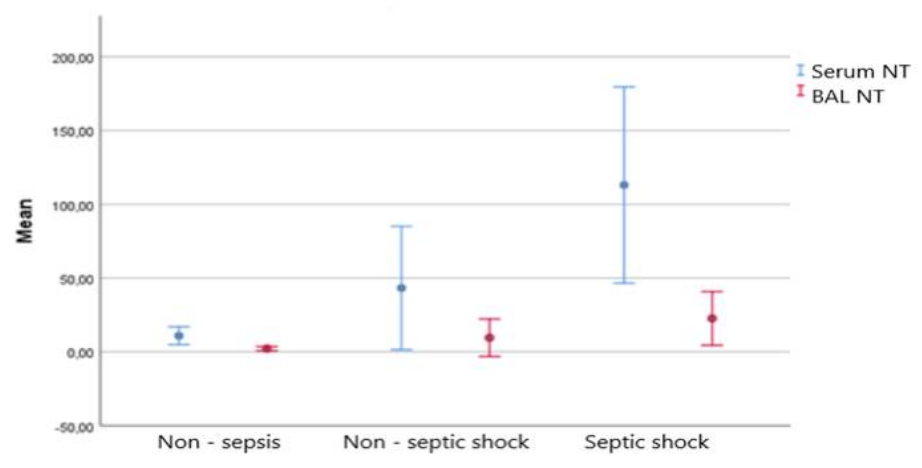

Figure 2. Mean serum and BAL NT values in sepsis patients with and without septic shock

Table 3: Correlations between clinical scoring systems and biomarkers

\begin{tabular}{lccc}
\hline & APACHE II & CCI & CPIS \\
\hline BAL NT (nmol/L) & $\mathrm{r}=0.485 ; \mathrm{p}=0.022$ & $\mathrm{r}=0.114 ; \mathrm{p}=0.614$ & $\mathrm{r}=0.511 ; \mathrm{p}=0.015$ \\
Serum NT (nmol/L) & $\mathrm{r}=0.706 ; \mathrm{p}=0.001$ & $\mathrm{r}=0.443 ; \mathrm{p}=0.039$ & $\mathrm{r}=0.379 ; \mathrm{p}=0.082$ \\
CRP $(\mathrm{mg} / \mathrm{L})$ & $\mathrm{r}=0.208 ; \mathrm{p}=0.353$ & $\mathrm{r}=-0.161 ; \mathrm{p}=0.475$ & $\mathrm{r}=0.171 ; \mathrm{p}=0.446$ \\
PCT $(\mathrm{ng} / \mathrm{ml})$ & $\mathrm{r}=0.208 ; \mathrm{p}=0.352$ & $\mathrm{r}=-0.146 ; \mathrm{p}=0.518$ & $\mathrm{r}=0.036 ; \mathrm{p}=0.873$ \\
Albumin $(\mathrm{mg} / \mathrm{dL})$ & $\mathrm{r}=-0.015 ; \mathrm{p}=0.947$ & $\mathrm{r}=0.399 ; \mathrm{p}=0.066$ & $\mathrm{r}=-0.242 ; \mathrm{p}=0.278$ \\
PLT $\left(10^{6} / \mathrm{mm}^{3}\right)$ & $\mathrm{r}=-0.100 ; \mathrm{p}=0.658$ & $\mathrm{r}=0.228 ; \mathrm{p}=0.306$ & $\mathrm{r}=0.168 ; \mathrm{p}=0.456$ \\
INR & $\mathrm{r}=-0.320 ; \mathrm{p}=0.147$ & $\mathrm{r}=-0.055 ; \mathrm{p}=0.807$ & $\mathrm{r}=-0.606 ; \mathrm{p}=0.088$ \\
Creatinine $(\mathrm{g} / \mathrm{dL})$ & $\mathrm{r}=0.701 ; \mathrm{p}=0.001$ & $\mathrm{r}=0.359 ; \mathrm{p}=0.101$ & $\mathrm{r}=0.275 ; \mathrm{p}=0.215$ \\
\hline
\end{tabular}

* Spearman or Pearson correlation test APACHE II: Acute Physiological and Chronic Health Assessment II, CCI: Charlson Comorbidity Index, CPIS: Clinical pulmonary infection score

or immature to total neutrophil ratio over $10 \%$. Septic shock is a subset of sepsis in which circulatory and cellular metabolism disorders are severe enough to increase the risk of mortality (1). Ventilator-associated pneumonia (VAP) was diagnosed in the presence of at least 2 of the following criteria: (a) body temperature over $38^{\circ} \mathrm{C}$ or under $36^{\circ} \mathrm{C}$, (b) purulent tracheobronchial secretion, (c) newly developed infiltration in chest $\mathrm{x}$-ray, and (d) clinical pulmonary infection score (CPIS) above 6 (12). Acute Physiology and Chronic Health Evaluation II (APACHE-II) score and Charlson comorbidity index (CCI) were calculated to determine disease severity and degree of comorbidity.
Statistics: The data were analyzed using SPSS version 21.0 statistical software package. Categorical data were presented as frequency distribution and percentage, continuous variables as mean \pm standard deviation and median (minimum-maximum values). Between-group comparisons of categorical data were made using chi-square test; the nonparametric Kruskal-Wallis and Mann-Whitney $U$ tests were used in comparisons of continuous data because the assumption of normality was not met. Receiver operating characteristic (ROC) curve analysis was used to determine the diagnostic value of biomarkers for sepsis. Cut-off values were determined and their sensitivity, specificity, positive predictive value (PPV), and negative 
predictive value (NPV) were calculated. Youden index $(J=$ Sensitivity + Specificity -1$)$ was used to identify cut-off values. A logistic regression model was created using the biomarkers that showed statistically significant differences between patients with and without sepsis (Model: Backward: LR. Entry: 0.05 and Removal: 0.10). For the biomarkers found to be significant in this model, ROC analysis was performed to determine the diagnostic value of their combined use. Relationships between clinical scores and biomarkers were evaluated using Spearman correlation analysis for nonparametric variables and Pearson correlation analysis for parametric variables. $\mathrm{P}$ values $<0.05$ were considered statistically significant.

\section{Results}

The mean age of the patients was $70.67 \pm 13.72$ years and $30(66 \%)$ were male. On evaluation of the primary foci of infection causing sepsis, the most common infectious focus was VAP $(n=21$, 95.4\%). The most frequently isolated infectious agent in BAL, urine, and peripheral and catheter blood cultures was Acinetobacter baumannii $(31.8 \%)$. The demographic characteristics, underlying diseases, risk factors, clinical scores, and initial biomarker levels of patients with and without sepsis are presented in Table 1. APACHE-II score, ICU length of stay, and duration of invasive mechanical ventilation were statistically significantly higher in patients with sepsis. Of the biomarkers evaluated at ICU admission, the differences in serum NT, BAL NT, CRP, PCT, albumin, PLT, INR, and creatinine levels between patients with and without sepsis were found to be significant. The cut-off points, diagnostic value, sensitivity, specificity, PPV, and NPV of the biomarkers found to differ significantly between patients with and without sepsis are presented in Table 2. At ICU admission, the biomarkers with the highest diagnostic value for sepsis were PCT, serum NT, and CRP. In a logistic regression model based on the 8 biomarkers that were significantly elevated in sepsis patients, serum NT and CRP were found to be independent risk factors for sepsis. The risk of sepsis increased by 1.067 -fold with each unit increase in serum NT (95\% CI: $1.004-1.135$; $\mathrm{p}=0.037)$ and by 1.025 -fold with each unit increase in CRP (95\% CI: $1.006-1.045 ; \mathrm{p}=0.010)$. The combined use of CRP and serum NT yielded a higher diagnostic value than either of the biomarkers when used alone. When serum NT and CRP were used together, sensitivity was $81.8 \%$, specificity was $91.3 \%$, and the area under the curve was $93.3 \%$ (95\% CI: $86.5-100 ; \mathrm{p}<0.001)$. ROC curves of serum and BAL NT, CRP, PCT, and the combination of serum NT and CRP for the diagnosis of sepsis are presented in Figure 1. Among the patients with sepsis, there were statistically significant positive correlations between APACHE-II score and serum NT and creatinine values. In addition, a moderate positive correlation was detected with BAL NT. There was also a moderate positive correlation between CCI and serum NT. CPIS showed a strong positive correlation with BAL NT. Correlations between the biomarkers and clinical scoring systems predicting prognosis in patients with sepsis are shown in Table 3. Among patients with sepsis, the mean serum and BAL NT values of those with and without septic shock are presented in Figure 2. Serum NT concentration was significantly higher in patients with septic shock compared to patients without septic shock (113.08 \pm 104.65 $\mathrm{nmol} / \mathrm{L}$ vs. $43.29 \pm 58.42 \mathrm{nmol} / \mathrm{L} ; \mathrm{p}=0.036) . \mathrm{BAL}$ NT showed no significant difference with or without septic shock $(\mathrm{p}=0.080)$.

\section{Discussion}

Sepsis is a severe, life-threatening syndrome caused by the host immune response to a systemic infection. Despite significant improvements in diagnosis and treatment, sepsis is still characterized by high mortality and morbidity. Early diagnosis is a crucial for the effective treatment of sepsis. As clinical symptoms are nonspecific, biomarkers are noted as utility tools in the diagnosis of sepsis. Patients who developed sepsis after trauma and burns were shown to have increased NT levels $(13,14)$. In a previous study evaluating the diagnostic value of NT and PCT in sepsis, NT was found to have lower diagnostic power than PCT, although the difference was not statistically significant (15). Our results also indicated that NT was significantly elevated in sepsis patients and had similar diagnostic value to PCT. In addition, we observed that NT had high specificity, which may be attributable to it being a direct indicator of inflammatory response activity. In another study that aimed to determine the diagnostic value of PCT and NT in the differentiation of sepsis and infection from systemic inflammation, both biomarkers were found to be almost equally effective. That study yielded lower diagnostic value $(66.9 \%)$, specificity $(78.3 \%)$, and sensitivity $(62.7 \%)$ for NT than the values determined in our study $(\underline{16})$. This may be related to the smaller proportion of critical patients in that study compared to ours. Findings in the same study that critical patients with septic 
shock and bloodstream infection had significantly higher peak NT values than patients with infection further supports this view. These data suggest that as a biomarker, NT has comparable value to PCT in the diagnosis of sepsis, especially in critical patients. In the literature, NT has been evaluated as a reliable prognostic and diagnostic marker for many infections such as periprosthetic joint infection, dengue virus, Crimean-Congo hemorrhagic fever, severe acute respiratory syndrome coronavirus-2 (SARS-CoV-2) (17-20). However, sepsis is the most common cause of elevated NT, and higher NT concentrations have been associated with poorer prognosis (21). NT was shown to have high diagnostic value for the development of multiple organ dysfunction syndrome in patients with sepsis (22). Fisgin et al. evaluated NT as a marker of mortality in patients with sepsis (23). In another study, elevated NT was found to increase the risk of septic shock by 2.3 -fold in a regression model created based on 57 patients with sepsis caused by gram-negative bacteria. This demonstrated its predictive value in determining the risk of progression to septic shock syndrome (24). Our study also showed that serum NT levels were significantly higher in the group of sepsis patients who progressed to septic shock compared to those who did not. APACHE II score is used to evaluate disease severity and mortality in patients admitted to the ICU (25). In our study, there was a very strong correlation between serum NT, and this commonly used scoring system, which is commonly used in the ICU to glean clues about patients' prognosis. These data indicate that NT, which has a central role in the pathogenesis of sepsis and reflects the activation of both monocytes/macrophages and endothelial cells may be predictive of prognosis. Alveolar macrophages, which play a critical role in the pulmonary immune response to infection, constitute more than $90 \%$ of the cells in BAL fluid. NT measured in BAL fluid reflects the level of alveolar macrophage activation (26). BAL NT levels were used to evaluate alveolar macrophage activation during lower respiratory tract infection in HIV-infected patients and it was shown that BAL NT levels were even more elevated in patients who developed respiratory tract infections (27). In a study where NT levels in BAL fluid were assessed in order to characterize macrophage activation status in patients with pneumonia, COPD, or interstitial lung disease and in a control group of patients with ischemic heart disease, BAL NT levels were found to be below the test threshold levels in the COPD, interstitial lung disease, and control groups, but were significantly elevated in patients with pneumonia. Moreover, BAL NT was strongly correlated with IL-8, which affects neutrophil uptake into the alveolar spaces in pneumonia patients (28). It has been shown in the literature that using biomarkers together increases their diagnostic value in sepsis. Gibot et al. demonstrated that with the combined use of polymorphonuclear leukocyte CD64 index, PCT, and sTREM-1 (soluble triggering receptor expressed on myeloid cells-1), values above the determined cut-off points yielded a larger area under the curve for the diagnosis of sepsis than each individual biomarker (29). Another study performed in the emergency department investigated the diagnostic value of biomarkers in sepsis and severe sepsis. A logistic regression model of PCT, IL-6, D-dimer, WBC, PLT, CRP, brain natriuretic peptide, and immature to total neutrophil ratio indicated that PCT, IL- 6 , and Ddimer were independent risk factors and the combined use of these three tests was superior in terms of diagnostic value, sensitivity, and specificity than each test when used alone (30). Consistent with previous studies, CRP and serum NT concentration were identified as independent risk factors in our study, and their combined use increased their diagnostic value in sepsis. This suggests that the combined use of biomarkers in the diagnosis of sepsis will be more beneficial in daily practice. The diagnostic value of serum NT in sepsis is as effective as the widely used biomarker PCT. Combined use with CRP increases the diagnostic value, specificity, and sensitivity of serum NT in sepsis. In addition, it can be used as a prognostic indicator and may be predictor of the rapidly emerging processes that lead to shock. Although BAL NT had a lower diagnostic value for sepsis, its correlation with clinical pulmonary infection score suggests that it may indicate disease severity in patients with VAP. Conflict of Interests: The authors have no conflict of interest.

\section{References}

1. Rhodes A, Evans LE, Alhazzani W, Levy MM, Antonelli M, Ferrer R, et al. Surviving sepsis campaign: international guidelines for management of sepsis and septic shock: 2016. Intensive Care Med 2017;43(3):304-377.

2. Rhee C, Dantes R, Epstein L, Murphy DJ, Seymour CW, Iwashyna TJ, et al. Incidence and trends of sepsis in US hospitals using clinical vs claims data, 2009-2014. JAMA 2017;318(13):12411249. 
Karaşahin ve ark. / The value of neopterin in the diagnosis of sepsis

3. Prucha M, Bellingan G, Zazula R. Sepsis biomarkers. Clin Chim Acta 2015;440:97103.

4. Wacker C, Prkno A, Brunkhorst FM, Schlattmann P. Procalcitonin as a diagnostic marker for sepsis: a systematic review and meta-analysis. Lancet Infect Dis 2013;13(5):426-435.

5. Reinhart K, Meisner M, Brunkhorst FM. Markers for sepsis diagnosis: what is useful? Crit-Care Clin 2006;22(3):503-519.

6. Samraj RS, Zingarelli B, Wong HR. Role of biomarkers in sepsis care. Shock 2013;40(5):358-365.

7. Koozi H, Lengquist M, Frigyesi A. Creactive protein as a prognostic factor in intensive care admissions for sepsis: a Swedish multicenter study. J Crit Care 2020;56:73-79.

8. Gregoriano C, Heilmann E, Molitor A, Schuetz P. Role of procalcitonin use in the management of sepsis. J Thorac Dis 2020;12(Suppl 1):S5-S15.

9. Fuchs D, Weiss G, Wachter H. Neopterin, biochemistry and clinical use as a marker for cellular immune reactions. Int Arch Allergy Immunol 1993;101(1):1-6.

10. Hoffmann G, Wirleitner B, Fuchs D. Potential role of immune system activation-associated production of neopterin derivatives in humans. Inflamm Res 2003;52(8):313-321.

11. Bevilacqua MP. Endothelial-leukocyte adhesion molecules. Annu Rev Immunol 1993;11(1):767-804.

12. Fartoukh M, Maître B, Honoré S, Cerf C, Zahar J-R, Brun-Buisson C. Diagnosing pneumonia during mechanical ventilation: the clinical pulmonary infection score revisited. Am J Respir Crit Care Med 2003;168(2):173-179.

13. Hensler $T$, Sauerland $S$, Lefering $R$, Nagelschmidt M, Bouillon B, Andermahr $J$, et al. The clinical value of procalcitonin and neopterin in predicting sepsis and organ failure after major trauma. Shock 2003;20(5):420-426.

14. Yao YM, Yu Y, Wang YP, Tian HM, Sheng ZY. Elevated serum neopterin level: its relation to endotoxaemia and sepsis in patients with major burns. Eur J Clin Invest 1996;26(3):224-230.

15. Sapa A, Rak A, Wybieralska M, Machoń J, Krzywonos-Zawadzka A, Zawadzki K, et al. Diagnostic usefulness of sCD163, procalcitonin and neopterin for sepsis risk assessment in critically ill patients. Adv Clin Exp Med 2017; 26(1):101-108.

16. Ruokonen E, Ilkka L, Niskanen M, Takala J. Procalcitonin and neopterin as indicators of infection in critically ill patients. Acta Anaesthesiol Scand 2002;46(4):398-404.

17. Hailemichael W, Kiros M, Akelew Y, Getu S, Andualem H. Neopterin: A Promising Candidate Biomarker for Severe COVID19. J Inflamm Res 2021;14:245-251.

18. Busch A, Jäger M, Engler H, Wasssenaar D, Bielefeld C, Wegner A. Diagnostic Accuracy of Synovial Neopterin, TNF- $\alpha$ and Presepsin in Periprosthetic Joint Infection: A Prospective Study. Z Orthop Unfall 2020.

19. Onguru P, Akgul EO, Akınc1 E, Yaman H, Kurt YG, Erbay A, et al. High serum levels of neopterin in patients with Crimean-Congo hemorrhagic fever and its relation with mortality. J Infect 2008;56(5):366-370.

20. Chandrashekhar C, Balaji K, Vasudev PH, Panachiyil GM, Babu T. Estimation of serum neopterin level as an early marker for detecting severe dengue infection. Int J Pediatr Adolesc Med 2019;6(4):151-154.

21. Kozlowska-Murawska J, Obuchowicz AK. Przydatność kliniczna oznaczania stężenia neopteryny [Clinical usefulness of neopterin]. Wiad Lek 2008;61(10-12):269272.

22. Zhang X, Chen Q, Ni S, Xiang Z, Zhou $X$, Huang Y. Serum neopterin and its significance as biomarker in differentiation of MODS from sepsis. Pteridines 2018;29(1):201-205.

23. Fisgin NT, Aliyazicioglu Y, Tanyel E, Coban AY, Ulger F, Zivalioglu M, et al. The value of neopterin and procalcitonin in patients with sepsis. South Med J 2010;103(3):216-219.

24. Delogu G, Casula MA, Mancini P, Tellan $G$, Signore L. Serum neopterin and soluble interleukin-2 receptor for prediction of a shock state in gram-negative sepsis. J Crit Care 1995;10(2):64-71.

25. Knaus WA, Draper EA, Wagner DP, Zimmerman JE. APACHE II: a severity of disease classification system. Crit Care Med 1985;13(10):818-829.

26. Dhondt J-L, Darras A, Mulliez P, Hayte J$\mathrm{M}$, Crinquette J. Unconjugated pteridines in bronchoalveolar lavage as indicators of 
alveolar macrophage activation. Chest 1989;95(2):348-351.

27. Evans M, Wansbrough-Jones M. Alveolar macrophage activation in HIV infection. J Infect 1996;33(2):91-94.

28. Buhling F, Tholert G, Kaiser D, Hoffmann B, Reinhold D, Ansorge S, et al. Increased release of transforming growth factor (TGF)-beta1, TGF-beta2, and chemoattractant mediators in pneumonia. J Interferon Cytokine Res 1999;19(3):271-278.
29. Gibot S, Bene MC, Noel R, Massin F, Guy J, Cravoisy A, et al. Combination biomarkers to diagnose sepsis in the critically ill patient. Am J Respir Crit Care Med 2012;186(1):65-71.

30. Zhao Y, Li C. [Diagnostic value of a combination of biomarkers in patients with sepsis and severe sepsis in emergency department]. Zhonghua Wei Zhong Bing Ji Jiu Yi Xue 2014;26(3):153-158. 